\title{
FGFR Gene Translocation
}

National Cancer Institute

\section{Source}

National Cancer Institute. FGFR Gene Translocation. NCI Thesaurus. Code C118377.

A cytogenetic abnormality that refers to the translocation of an FGFR family gene to a new chromosomal location. 